\title{
Antioxidative, antiproliferative, and apoptosis effect of Coleus tuberosus flesh and peel ethanol extracts on cervical cancer cell lines
}

\author{
Mutiara Nugraheni ${ }^{1 *}$ (D), Windarwati Windarwati ${ }^{2}$, Badraningsih Lastariwati $^{1}$ \\ ${ }^{1}$ Culinary Art Education, Engineering Faculty, Yogyakarta State University, Yogyakarta, Indonesia. \\ ${ }^{2}$ Department of Clinical Pathology, Medicine Faculty, Gadjah Mada University, Yogyakarta, Indonesia.
}

\begin{tabular}{l}
\hline ARTICLE INFO \\
\hline Article history: \\
Received on: June 24, 2021 \\
Accepted on: September 21, 2021 \\
Available Online: January 07, 2022 \\
\hline
\end{tabular}

Key words:

Coleus tuberosus, antioxidant cellular, apoptosis, cell cycle arrest

\begin{abstract}
The purpose of this study is to determine the antioxidant activity, antiproliferation, apoptosis, and cell cycle arrest induced by Coleus tuberosus flesh and peel extracted with ethanol. The antioxidant activity was determined using the 1,1-diphenylpricrylhydrazyl and cellular antioxidant assays, and the antiproliferative activity was determined using the 3(4,5-dimethylthiazol-2-yl)-2,5-diphenyltetrazolium bromide assay. Flow cytometry was used to assess cell cycle arrest, and acridine orange-ethidium bromide staining was used to assess apoptosis-induced ability. The results show that the C. tuberosus peel extract has higher antioxidant activity than the flesh extract. Coleus tuberosus flesh ethanol extract (CFEE) and C. tuberosus peel ethanol extracts' (CPEE) antioxidant activities inhibitory concentration $50\left(\mathrm{IC}_{50}\right)$ were $1290.00 \pm 1.58 \mathrm{~g} / \mathrm{ml}$ and $310.97 \pm 0.32 \mu \mathrm{g} /$ $\mathrm{ml}$, respectively. The $C$. tuberosus peel extract has greater antiproliferative activity than the flesh extract. The $C$. tuberosus flesh and peel extracts had antiproliferative activities $\left(\mathrm{IC}_{50}\right)$ of $651.35 \pm 4.24$ and $366.41 \pm 3.52 \mu \mathrm{g} / \mathrm{ml}$, respectively. The flesh and peel extracts cause apoptosis in HeLa cells. Cell cycle arrest in sub-G1 (M) and cell cycle inhibition in G0-G1 are caused by the C. tuberosus peel extract. According to this study, the CFEE and CPEEs have the potential to be a source of natural antioxidants and antiproliferation of cervical cancer.
\end{abstract}

\section{INTRODUCTION}

Cervical cancer is one of the cancers which kills women in developing countries every year [1]. This is in line with the incidence of cervical cancer in Indonesia, the second cause of women's death at 23.4 per 100,000 , an average death rate of 13.9 per 100,000 [2]. The known stage of cancer and the rate at which treatment is administered determine a person's life expectancy. Assume the cancer is discovered and treated in its early stages. In that case, the life expectancy is approximately $70 \%-75 \%, 60 \%$ in the second stage, and $25 \%$ in the third stage, and it is difficult to survive in stage four sufferers.

Eating foods high in biologically active compounds and antioxidants can help prevent cancer because diet can prevent

\footnotetext{
*Corresponding Author

Mutiara Nugraheni, Culinary Art Education, Engineering Faculty, Yogyakarta State University, Yogyakarta, Indonesia. E-mail: mutiara_nugraheni@uny.ac.id
}

$30 \%-40 \%$ of cases. Coleus tuberosus is one plant that has antitumor properties. Coleus tuberosus belong to the tuber vegetable species, belonging to the same nation as Solanum tuberosum and classified in the Family Lamiaceae and the subfamily Nepetoideae. Coleus tuberosus belongs to a group of plants used as food and medicine based on ethnobotany and phylogeny in Plectranthus [3].

Some research suggests that $C$. tuberosus can potentially have an antitumor, antioxidant, and antiproliferation effects in cancer cells [4-6]. Triterpenic acid compounds with antioxidant and antiproliferative properties include ursolic acid, oleanolic acid, and maslinic acid. Triterpenic acids are among the biologically active compounds found in C. tuberosus (ursolic acid, oleanolic acid, and maslinic acid) [6,7]. Ursolic acid, oleanolic acid, and maslinic acid are triterpenic acid compounds with antioxidant and antiproliferative properties [8-11].

HeLa cells are cervical cancer cells that are often used in research. A distinctive feature of cancer cells is rapid proliferation. Proliferation in cancer cells is uncontrolled growth and infinite 

on cervical cancer cell lines 2022;10(01):164-171

cleavage. Cancer is caused by the imbalance of active oxygen and antioxidant defense system in the body, which can cause oxidative stress and promote the damage of protein, DNA, and RNA, leading to abnormal cell growth $[12,13]$. Prevention of cancer through bioactive compounds of plants can stop carcinogenesis and inhibit proliferation. One way to achieve that is by consuming phytochemical compounds contained in foods that have the ability as cellular antioxidants. Inhibition of cancer cell proliferation due to bioactive compounds can interact with cancer processes at the genetic level and modify the detoxification side of the drug, DNA repair, and cell proliferation. Dietary interventions containing phytochemical compounds that have the ability as cellular antioxidants can be a key strategy to prevent the development of cancer.

The study aims to determine the potential of different parts of the C. tuberosus ethanol extract on antioxidative, antiproliferative, and apoptosis effect and cell cycle arrest in HeLa cell lines.

\section{MATERIALS AND METHODS}

\subsection{Preparation of $C$. tuberosus Flesh Ethanol Extract (CFEE) and $C$. tuberosus Peel Ethanol Extracts (CPEE) Through a Maceration Process}

Coleus tuberosus was taken from a 3-month-old plant. A peeler was used to separate the tuber and peel. Coleus tuberosus flesh and peel were dried for 24 hours in a drying cabinet at $40^{\circ} \mathrm{C}$. The dried flesh and peel were then size-reduced and sifted through a sieve Tyler size $80 \mathrm{mesh}$. The flesh and peel flour was then frozen $\left(-20^{\circ} \mathrm{C}\right)$ until needed. For 7 days, the $C$. tuberosus tuber and peel maceration process employed ethanol at a 1:5 ratio. Following that, the solution was filtered through Whatman paper and dried on a rotary evaporator at $45^{\circ} \mathrm{C}$. The extract that resulted was kept at $20^{\circ} \mathrm{C}$.

\subsection{Analysis of Antioxidant Activity by the 1,1-Diphenylpri crylhydrazyl (DPPH) Method}

The ability of free radical scavengers was measured to assess antioxidant activity [14]. The hydrogen supply capacity of the CFEE or CFEE to capture radicals was measured using DPPH. Two milliliters of a $0.1 \mathrm{mM}$ DPPH methanol solution, plus 100 $2,000 \mu \mathrm{L}$ of ethanol extract from $C$. tuberosus flesh or peel of varying concentrations, was added. After 30 minutes, the reaction mixture discolored, and it was read at $517 \mathrm{~nm}$ against blanks. The inhibitory concentration $50\left(\mathrm{IC}_{50}\right)$ of the CFEE or CPEE required to capture $50 \% \mathrm{DPPH}$ was used to demonstrate antioxidant ability. The lower the $\mathrm{IC}_{50}$, the greater the antioxidant capacity. The $\mathrm{IC}_{50}$ values are calculated by using linear regression between extract concentrations and radical capture percentages.

\subsection{Cell Culture}

For evaluation of the activity of cellular antioxidants, antiproliferation, cell cycle, and apoptosis, frozen cells (HeLa cells from American Type Culture Collection (ATCC): CCL2TM) from liquid nitrogen storage were laid at room temperature until partially melted, then inserted in a conical tube $15 \mathrm{ml}$, plus $10 \mathrm{ml}$ of washing media, and shaken. The pellets were centrifuged at $750 \mathrm{~g}$ for 7 minutes and then added to the culture medium [Roswell Park Memorial Institute (RPMI)] in a flask. RPMI culture media were used to culture HeLa cells. In laminar airflow, all activities were carried out aseptically. The cell was then incubated at $37^{\circ} \mathrm{C}$ with a $5 \% \mathrm{CO}_{2}$ flow. Cell development was monitored on a daily basis, and if the media began to turn yellow, it was replaced with new media. Media on HeLa cells were removed and washed with sufficient Phosphate Buffer Saline (PBS). After 4-5 weeks of incubation, cells reached confluence, and then they were detached after trypsinization $[0.05 \%$ trypsin with Ethylenediaminetetraacetic acid (EDTA) in PBS] and transferred to $75 \mathrm{~cm}^{2}$ flasks for continued growth. The culture medium was renewed once needed until cells reached $80 \%-90 \%$ confluency. The 7 th -15 th passages of HeLa were used in the experiment.

\subsection{Analysis of Cellular Antioxidant Activity}

The antioxidant activity of $C$. tuberosus on HeLa cells was studied $[15,16]$. HeLa cells were grown in a microplate with 96 wells and an RPMI medium. RPMI plus fetal bovine serum $10 \%$ $(\mathrm{v} / \mathrm{v})$, penicillin $100 \mathrm{U}$, and streptomycin $100 \mathrm{mg} / \mathrm{ml}, \mathrm{CO}_{2}$ at $5 \%$, and temperature $37^{\circ} \mathrm{C}$ are the conditions. The growth medium was processed and washed with PBS after being placed on the microplate for 20 hours. Coleus tuberosus tuber and peel ethanol extracts $100-800 \mu \mathrm{g} / \mathrm{ml}$ in Dimetil sulfoksida (DMSO) was used in various concentrations.

Three wells are treated for 20 minutes with different concentrations of $100 \mu \mathrm{l}$ CFEE or CPEE, followed by 30 minutes with $25 \mathrm{mM}$ Dichlorodihydrofluorescein diacetate (DCFHDA) dissolved in medium and $100 \mathrm{ng} / \mathrm{ml}$ Phorbol 12-myristate 13-acetate (PMA) DMSO. A Becton Dickinson FACS (BD FACS) Calibur flow cytometer with a $535 \mathrm{~nm}$ wavelength was used to fluoresce 20,000 HeLa cells. The percentage of reactive oxygen species reduction was used to calculate cell antioxidant activity:

Percentage of ROS reduction $=\left(\right.$ Fit $\left._{\mathrm{o}}-\mathrm{Fit}_{1}\right) \times 100 /\left(\mathrm{Fit}_{\mathrm{o}}-\mathrm{Fit}_{2}\right)$, where Fit ${ }_{0}$ are cells subjected to oxidative stress, Fit ${ }_{1}$ are cells subjected to extract treatment, and Fit ${ }_{2}$ are cells subjected to no oxidative stress [17].

\subsection{Evaluation of Antiproliferation}

Incubating HeLa cells with CFEE or CPEE resulted in antiproliferative activity [18]. HeLa cells are used in research (ATCC). Cell concentrations $(1.5 \times 104$ cells $/ \mathrm{ml})$ were plated in 96-well plates. At $5 \% \mathrm{CO}_{2}$ and $37^{\circ} \mathrm{C}, 10 \%(\mathrm{v} / \mathrm{v})$ fetal bovine serum, $100 \mathrm{U}$ penicillin, and $100 \mathrm{mg} / \mathrm{ml}$ streptomycin were added to Dulbecco's modified eagle medium (DMEM). It was left for 24 hours. A $100-800 \mu \mathrm{g} / \mathrm{ml}$ ethanol extract of C. tuberosus flesh or peel was added to HeLa cancer cells. The extract contained $0.5 \%$ of ethanol which was applied as control. The 3(4,5-dimethylthiazol2-yl)-2,5-diphenyltetrazolium bromide (MTT) assay was used to assess cancer cell viability. The concentration of HeLa cells in the solution was $1.5 \times 104$ cells $/ \mathrm{ml}$. The HeLa was washed with HBBS after 24 hours of incubation. The cells were then incubated for 4 hours in $50 \mu \mathrm{l}$ of an MTT solution $(0.5 \mathrm{mg} / \mathrm{ml}$ in DMEM). The next step was to add the stop solution, let it sit overnight, and 
then measure the absorbance at $570 \mathrm{~nm}$ with a multilabel plate reader. The following formula calculates the number of viable cells using the MTT assay:

$$
\text { HeLa cells viability }(\%)=(\text { treatment absorbance/without }
$$$$
\text { treatment absorbance) } \times 100 \text {. }
$$

\subsection{Apoptosis Induction Evaluation}

Acridine orange and ethidium bromide (AO-EB) staining was used to assess morphological changes caused by apoptosis induction in HeLa cells treated with the CFEE or CPEE. On the coverslip, HeLa cells were plated at $10^{5}$ cells per well. After that, the growth medium was replaced with one containing the CFEE or CPEE at a concentration of 15.875 or $31.25 \mathrm{~g} / \mathrm{ml}$, respectively. This was incubated for 24 hours at $5 \% \mathrm{CO}_{2}$ and $37^{\circ} \mathrm{C}$. The next step was to remove the growth medium and incubate for 5 minutes with acridine orange-ethidium bromide at a concentration of $100 \mathrm{~g} / \mathrm{ml}$ PBS and place the coverslip over the glass object, and then this was observed with a fluorescence microscope (Zeiss MC 80) [19].

\subsection{Cell Cycle Arrest}

In a 6 -well plate, $10^{6}$ cells per well were distributed and cultivated at $37^{\circ} \mathrm{C}$ for cell adaptation. For 24 hours, HeLa cells were exposed to the CFEE or CPEE at concentrations of $7.8125,15.625,31.25$, 62.5 , and $125 \mathrm{~g} / \mathrm{ml}$. The cultivated cells were removed after 24 hours and washed twice with ice-cold PBS. The cells were fixed and permeabilized for 1 hour at $4^{\circ} \mathrm{C}$ with ice-cold $70 \%$ ethanol. The HeLa cells were then rinsed in PBS and resuspended in a solution containing $50 \mathrm{ml} / \mathrm{ml}$ propidium iodide dye and $250 \mathrm{mg} / \mathrm{ml} \mathrm{RNase}$ A. The cell suspension was incubated at room temperature for 30 minutes before being utilized for fluorescence-activated cell sorting with 10,000 cells per group (FACS; Caterplus Flow Cytometry; Becton Dickinson Co., Germany) [20]. The ModFit LT Cell Cycle 3.0 analysis software was used to determine the percentage of $\mathrm{HeLa}$ cells in the G0-G1, S, and G2/M phases (Becton Dickinson).

\subsection{STATISTICAL ANALYSIS}

The data displayed are the mean standard deviation $( \pm$ SD) in triplicate. Analyzing variance and the least significant difference test were used to test in vitro antioxidant activity, cellular antioxidant activity, and antiproliferation.

\section{RESULTS AND DISCUSSION}

\subsection{Antioxidant Activity Evaluation}

The DPPH method was used to assess antioxidant activity. The DPPH method was used to demonstrate that the CFEE or CPEE has antioxidant activity in vitro (Table 1 ). The antioxidant activity was expressed as an $\mathrm{IC}_{50}$, indicating that the free radical scavenger (DPPH) has a 50\% capacity. The higher the antioxidant activity, the lower the $\mathrm{IC}_{50}$. As a result, the peel ethanolic extract has higher antioxidant activity than the flesh extract $C$. tuberosus. The antioxidant activity of the CFEE or CPEE was supported by the presence of biologically active compounds such as oleanolic
Table 1: $\mathrm{IC}_{50}$ CFEE and CPEE by the DPPH method.

\begin{tabular}{ll} 
Compounds & $\mathbf{I C}_{\mathbf{5 0}}(\boldsymbol{\mu g} / \mathbf{m l})$ \\
CFEE & $1,290.00 \pm 1.58^{\mathrm{b}}$ \\
CPEE & $310.97 \pm 0.32^{\mathrm{a}}$ \\
\hline
\end{tabular}

Difference notation: difference significant at $p<0.05$.

acid, maslinic acid, ursolic acid, phenol, and flavonoids, with the peel having a higher concentration than the flesh $[6,7,21,22]$. Ursolic acid, oleanolic acid, maslinic acid, and phytosterols acted as free radical scavengers [23-29]. The difference in the number of bioactive compounds was thought to have an impact on its antioxidant activity.

\subsection{Cellular Antioxidants Activity Evaluation}

Figure 1 demonstrated that the CFEE or CPEE could reduce PMA-induced reactive oxygen species in HeLa cells in a dosedependent manner. The Reactive Oxygen Species (ROS) reduction percentages in HeLa cells incubated with the CFEE or CPEEs at various concentrations of $100,200,400$, and $800 \mu \mathrm{g} / \mathrm{ml}$ were $44.32 \pm 0.95,52.52 \pm 0.20,72,77 \pm 0.64$ and $80.135 \pm 0,52$, respectively. The percentages of ROS reduction in HeLa cells incubated with the CFEE or CPEE at different concentrations of $100,200,400$, and $800 \mu \mathrm{g} / \mathrm{ml}$ were $25.67 \pm 0.95,42.98 \pm 0.20,59$, $12 \pm 0.64$ and $66.23 \pm 0.07$, respectively.

The exceeding level of reactive oxygen species in cells will attack DNA, lipids, or proteins that will induce oxidation reactions and damage cell membranes to activate key enzymes on some signaling pathways [30]. The ability of the CFEE or CPEE to reduce reactive oxygen species is related to eliminating reactive oxygen species that attack cell membranes. Ursolic acid, oleanolic acid, maslinic acid, phytosterols, phenols, and flavonoids can maintain the cell membrane fluidity by scavenging reactive oxygen species so that communication signals at the cellular level continue to function normally, including signals related to the activation of antioxidant enzymes [Nuclear erythroid 2-related factor 2 Antioxidant Response Element (Nrf2ARE)], transcription factors that regulate the genes encoding antioxidant defense system [31,32]. Higher expression of Nrf2ARE can enhance the antioxidant defense system in cells.

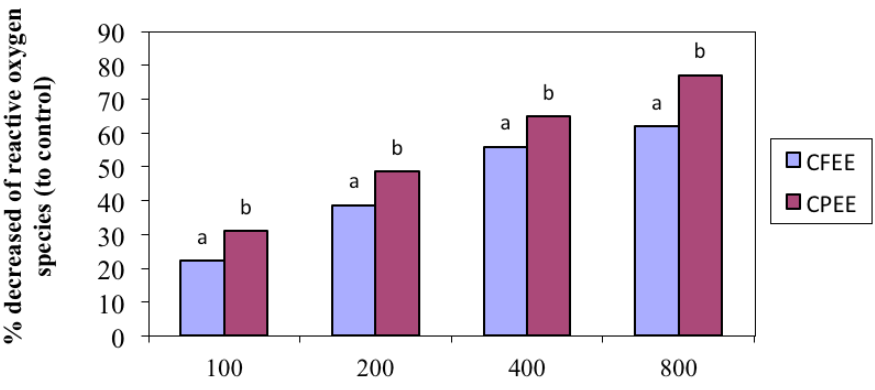

Concentration of Coleus tuberosus ethanolic extract $(\mu \mathrm{g} / \mathrm{ml})$

Figure 1: At 24 hours incubation, the percentage decrease in reactive oxygen species of HeLa cells with various concentrations of the CFEE and CPEE. The data displayed is the mean of the experimental triplicates. There are significant differences between the letters ( $p 0.05)$. 

on cervical cancer cell lines 2022;10(01):164-171

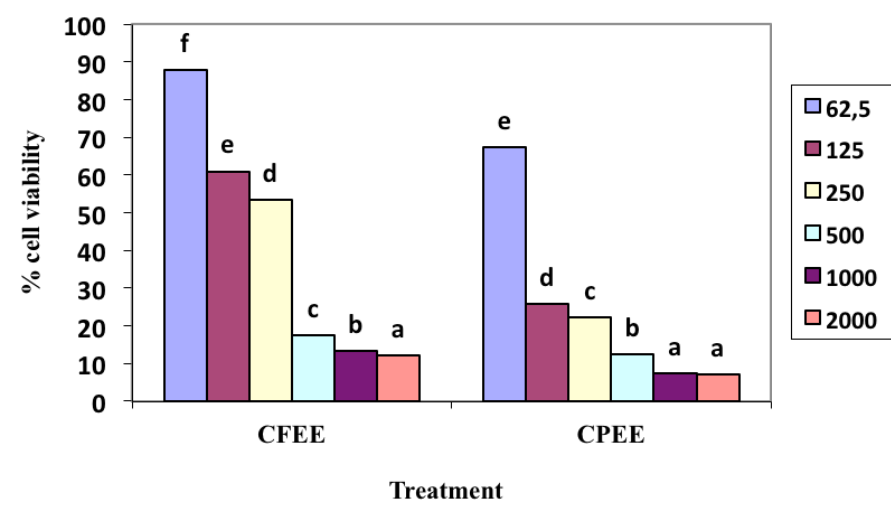

Figure 2: Percentage of cell viability in the treatment of various concentrations of the CFEE and CPEE at 24 hours incubation. The data were presented as the average of the triplicate experiments. Different letters indicate a significant difference $(p<0.05)$.

The ability to neutralize singlet oxygen $\left({ }^{1} \mathrm{O}_{2}\right)$, superoxide anion radicals $\left(\mathrm{O}_{2}{ }^{\circ}\right)$, hydrogen peroxide $\left(\mathrm{H}_{2} \mathrm{O}_{2}\right)$, and hydroxyl radicals $\left({ }^{\circ} \mathrm{OH}\right)$ will be affected by PMA induction. The Coleus ethanol extract contains biologically active compounds that can boost cells' antioxidant defense systems [Catalase (CAT), Superoxide dismutase (SOD), Glutathione peroxidase (GPx), vitamin E, vitamin C, carotene, and Glutathion (GSH)] and reduce oxidative stress [33-36]. The antioxidants in the CFEE or CPEE work as free radical scavengers thus reducing reactive oxygen species in PMA-induced HeLa cells.

\subsection{Antiproliferation Activity}

The MTT method was used to assess the antiproliferative activity of the CFEE or CPEE in HeLa cells. The cancer cells were treated with a concentration range of $62.5-2,000 \mathrm{~g} / \mathrm{ml}$ and incubated for 24 hours (Fig. 2). Figure 2 shows that, depending on the dose, incubating HeLa cells with the CFEE or CPEE can reduce the percentage of viable cells. The $\mathrm{IC}_{50}$ of the CFEE or CPEE treatment is shown in Table 2.

The interaction of biologically active compounds in the CFEE or CPEE provides a synergistic effect and determines its antiproliferative capacity. The CFEE or CPEEs can both inhibit HeLa cell proliferation. The $C$. peel extract has superior antiproliferative properties to the flesh extract. This is consistent with the discovery that the peel contains more biologically active compounds than the flesh. Coleus contains the following biologically active compounds that support antiproliferative activity: Ursolic Acid (UA), Oleanolic Acid (OA), maslinic acid, phytosterols, phenols, and flavonoids that have antiproliferative activity in some cancer cells [37-39]. These biologically active compounds can reduce Nuclear Faktor $\mathrm{k}$ $\mathrm{B}(\mathrm{NFkB})$ regulatory genes, which play a key role in developing and progressing specific cancer cells, such as proliferation, migration,

Table 2: $\mathrm{IC}_{50}$ of antiproliferation CFEE and CPEE on HeLa cells.

\begin{tabular}{ll} 
Compound & $\mathbf{I C}_{50}(\boldsymbol{\mu g} / \mathbf{m l})$ \\
CFEE & $651.35 \pm 4.24^{\mathrm{b}}$ \\
CPEE & $366.41 \pm 3.52^{\mathrm{a}}$ \\
\hline
\end{tabular}

Difference notation: difference significant at $p<0.05$. and apoptosis [40-43]. Low NFkB expression results in a decrease in cyclin D1 and an increase in tumor suppressor factors (such as p53, p21, and p27), which inhibits HeLa cell proliferation. As a result, the possible antiproliferation mechanism of the CFEE or CPEE reduces oxidative stress by lowering reactive oxygen species. It can control the cell cycle and gene expression that regulates cell proliferation cyclin D1 [44-48].

\subsection{Apoptosis-Induced Activity}

The CFEE or CPEE at a concentration of 15.625 or $31.25 \mu \mathrm{g} /$ $\mathrm{ml}$ can induce apoptosis in HeLa cells (Fig. 3). The induction of HeLa cell apoptosis can be detected using Acridine Orange (AO)-EB staining. Evaluation for live and dead cells undergoing apoptosis can use the combination of AO-EB. When AO-EB binds to living cells' double-stranded DNA, it emits green fluorescence. Simultaneously, when AO-EB binds to single-stranded DNA in dead cells, the fluorescence turns red. Cells that enter the early stage of apoptosis turn green, and cells that enter the late stage of apoptosis have their DNA broken and turn red. Meanwhile, in the final apoptosis process, DNA is fragmented and will be red [49].

Due to changes in cell membrane permeability, cells undergo apoptosis. Changes in cell membrane permeability cause AO-EB to enter and embed in cells with the orange-character DNA [50]. While bright green cells show cells have early apoptosis, chromatin condensation causes chromatin to absorb more color than control, and the cells are bright green. However, the cells are still alive, so only AO can color living cells [51]. Coleus tuberosus contains bioactive compounds such as oleanolic acid, ursolic acid, maslinic acid, and phytosterols, which are apoptosis inducers [52-55].

\subsection{Evaluation of Cell Cycle Arrest}

Flow cytometry was used to assess cell cycle arrest in HeLa cells (Beckton Coulter, USA). HeLa cells were induced by various concentrations of the CFEE or CPEE, i.e., 7.812, 15.625, 31.25, 62.5, and $125 \mu \mathrm{g} / \mathrm{ml}$ (Fig.4 and Fig.5).

The CFEE did not significantly inhibit HeLa cell cycles in the M1 phase, G0-G1 phase, S-phase, or G2-M phase. The CPEE can inhibit the G2-M phase and induce cell death, as evidenced by an increase in the percentage of cells in the sub-G1 (M1) phase. Increased concentrations of the CPEE impact cell death, as evidenced by an increase in the percentage of sub-G1 (M1) cells and an increase in cell cycle arrest G0-G1 phase. This finding is consistent with previous research indicating that increasing the concentration of extracts of a cell-induced product increases cell death by increasing sub-G1 (M) and G0-G1 cell cycle arrest [56,57]. The CPEE could inhibit the cell cycle, causing cell accumulation in a hyperdiploid, and then undergo apoptosis.

\section{CONCLUSION}

The CPEE and CFEEs have antioxidant, antiproliferative, apoptotic, and cell cycle arrest activity. In terms of antioxidant activity, antiproliferative activity, and ability to induce cell cycle arrest, the $C$. tuberosus peel extract outperformed the flesh extract. According to this finding, the CFEE and CPEEs may be a source of natural antioxidants and cancer-preventive agents. 


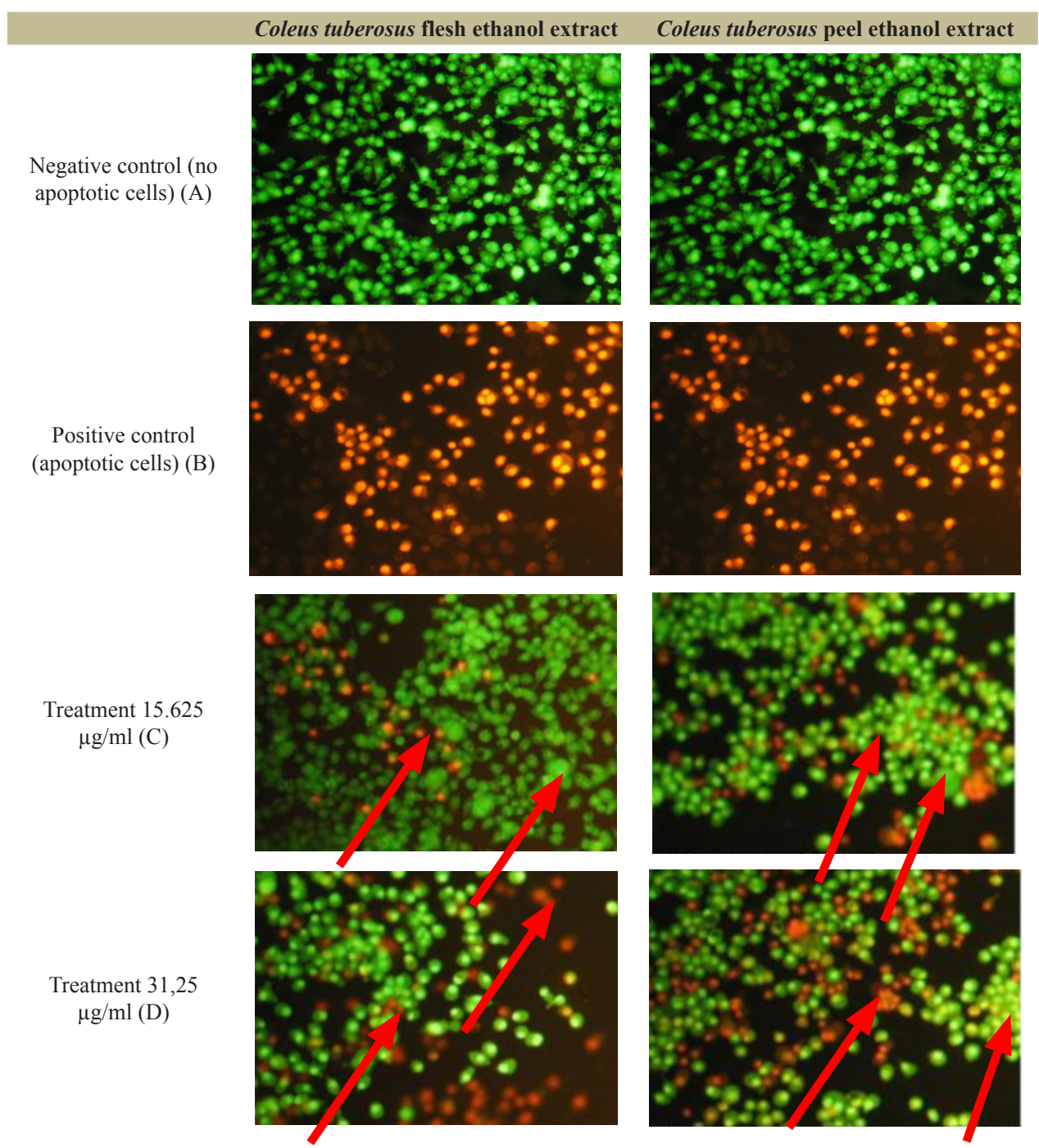

Figure 3: Induction of apoptosis in HeLa cells with the CFEE or CPEE. (A) Negative control; (B) positive control; (C and D) flesh or peel ethanolic extract of C. tuberosus. Morphological observations of apoptotic HeLa cells were made using acridine orange-ethidium bromide staining and a fluorescent microscope. Negative control (A) of living cells, normal shape, and green color; positive control (B), cell apoptosis; (C and D) induction of apoptosis, and some cells have died and deformed, and the color of the cells changed from light green to orange. Initial apoptosis (light green color), final apoptosis (orange color).

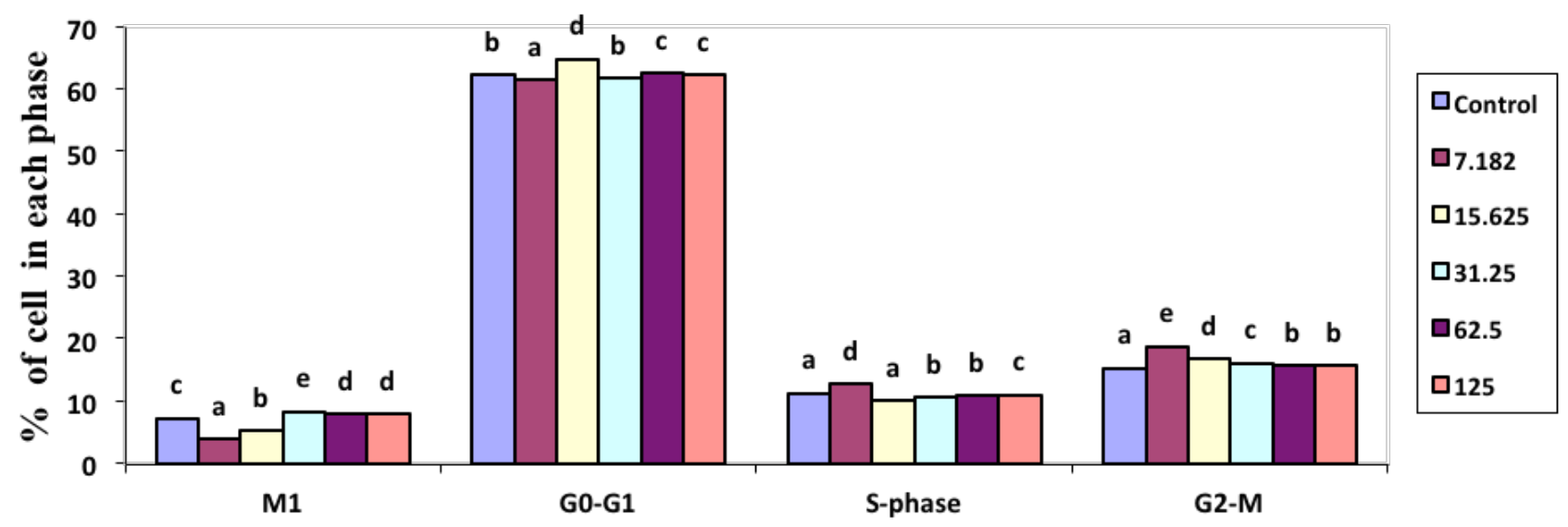

Figure 4: The effect of the CFEE on cell cycle arrest. HeLa cells were treated for 24 hours with various extract concentrations, namely, 7.8125, 15.625, $31.25,62.5$, and $125 \mu \mathrm{g} / \mathrm{ml}$, and without extract (as a control). Propidium Iodide (PI)-stained cells were analyzed with a flow cytometer. The use of a different letter demonstrates a significant difference $(p<0.05)$. 


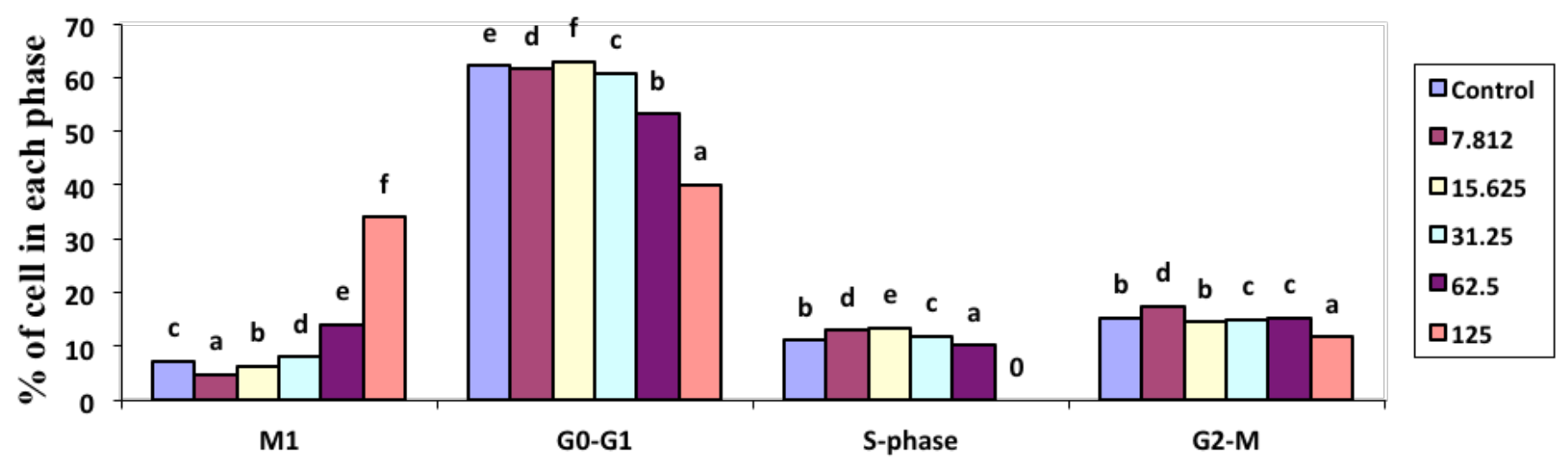

Figure 5: The effect of the CPEE on cell cycle arrest. HeLa cells were treated for 24 hours with various extract concentrations, namely, 7.8125, 15.625, 31.25, 62.5 , and $125 \mu \mathrm{g} / \mathrm{ml}$, and without extract (as a control). PI-stained cells were analyzed with a flow cytometer. The use of a different letter demonstrates a significant difference $(p<0.05)$.

\section{AUTHORS' CONTRIBUTIONS}

$\mathrm{MN}$ participated in the concept and research design, data collection, data analysis, interpretation of analysis results, and writing the manuscript. $\mathrm{W}$ and $\mathrm{BL}$ participated in designing the research, statistical analysis, and revising the important content of the manuscript. The manuscript has been approved by all of the authors.

\section{ACKNOWLEDGMENTS}

The authors would like to express their gratitude to Yogyakarta State University for providing them with Research Grant 233a/ HB-BOPTN/UN34.21/2014.

\section{CONFLICTS OF INTEREST}

The authors declare that they have no conflicts of interest.

\section{ETHICAL APPROVAL}

There were no animal or human subjects in this study.

\section{REFERENCES}

1. Krstic M, Stojadinovic M, Smiljanic K, Stanic-Vucinic D, Velickovic TC. The anti-cancer activity of green tea, coffee and cocoa extracts on human cervical adenocarcinoma HeLa cells depends on both prooxidant and anti-proliferative activities of polyphenols. RSC Adv 2015;5(5):3260-8.

2. RI K. Hari Kanker Sedunia 2019. Kementerian Kesehatan Republik Indonesia, Jakarta, Indonesia, 2019.

3. Imre M, Csedö, K. 2007. Chemical differences and simi-larities in the family Lamiaceae. Revista de Medicina si Farmacie 53: 1-14.

4. Hsum YW, Yew WT, Hong PLV, Soo KK, Hoon LS, Chieng YC, et al. Identificaton and evaluation of potential anti-tumor promoting compounds from tubers of Coleus tuberosus. In International Symposium on Natural Products in Cancer Therapy, Naples, Italy, pp 23-6, 2008.

5. Ali AM, Mooi LY, Yih KY, Norhanom AW, Saleh K, Lajis NH, et al. Anti-tumor promoting activity of some malaysian traditional vegetable (ulam) extracts by immunoblotting analysis of Raji cells. Nat Prod Sci 2000;6(3):147-50.
6. Nugraheni M, Santoso U, Wuryastuti H. Potential of Coleus tuberosus as an antioxidant and cancer chemoprevention agent. Int Food Res J 2011;18(4):147-80.

7. Mooi LY, Wahab NA, Lajis NH, Ali AM. Chemopreventive properties of phytosterols and maslinic acid extracted from Coleus tuberosus in inhibiting the expression of EBV early-antigen in Raji cells. Chem Biodivers 2010;7(5):1267-75.

8. Chouaïb K, Romdhane A, Delemasure S, Dutartre P, Elie N, Touboul D Regiospecific synthesis, anti-inflammatory and anticancer evaluation of novel 3,5-disubstituted isoxazoles from the natural maslinic and oleanolic acids. Ind Crops Prod 2016;85:287-99.

9. CC. Ursolic acid and other pentacyclic triterpenoids: anticancer activities and occurrence in berries. In: Berries and cancer prevention. Springer. Editor: Stoner GD, Seeram NP. Springer Science+Business Media, LLC, New York, NY 2011: 41-9.

10. Juan ME, Planas JM, Ruiz-Gutierrez V, Daniel H, Wenzel U. Antiproliferative and apoptosis-inducing effects of maslinic and oleanolic acids, two pentacyclic triterpenes from olives, on HT-29 colon cancer cells. Br J Nutr 2008;100(1):36-43.

11. Kontogianni VG, Tomic G, Nikolic I, Nerantzaki AA, Sayyad N, StosicGrujicic S, et al. Phytochemical profile of Rosmarinus officinalis and Salvia officinalis extracts and correlation to their antioxidant and antiproliferative activity. Food Chem 2013;136(1):120-9.

12. Gupta RK, Patel AK, Shah N, Choudhary AK, Jha UK, Yadav UC, et al. Oxidative stress and antioxidants in disease and cancer: a review. Asian Pac J Cancer Prev 2014;15(11):4405-9.

13. Silva GÁF, Nunes RAL, Morale MG, Boccardo E, Aguayo F, Termini L. Oxidative stress: therapeutic approaches for cervical cancer treatment. Clinics 2018;73:e548s.

14. Singh R, Singh B, Singh S, Kumar N, Kumar S, Arora S. Investigation of ethyl acetate extract/fractions of Acacia nilotica Willd. Ex Del as potent antioxidant. Rec Nat Prod 2009;3(3):131.

15. Wolfe KL, Liu RH. Cellular antioxidant activity (CAA) assay for assessing antioxidants, foods, and dietary supplements. Agric Food Chem [Internet] 2007;55(22):8896-907.

16. Liu RH, Finley J. Potential cell culture models for antioxidant research. J Agric Food Chem 2005;53(10):4311-4.

17. Muanda FN, Bouayed J, Djilani A, Yao C, Soulimani R, Dicko A. Chemical composition and, cellular evaluation of the antioxidant activity of Desmodium adscendens leaves. Evid Based Complement Altern Med 2010;2011:620862.

18. Hogan S, Chung H, Zhang L, Li J, Lee Y, Dai Y, et al. Antiproliferative and antioxidant properties of anthocyanin-rich extract from açai. Food Chem 2010;118(2):208-14. 
19. Meiyanto E, Agustina D, Suparjan AM, Da IM. PVG-O induces apoptosis on T47D breast cancer cells line through caspase-3 activation. J Kedokt Yars 2007;15(2):75-9.

20. Cho JH, Lee JG, Yang YI, Kim JH, Ahn JH, Baek NI, et al. Eupatilin, a dietary flavonoid, induces $\mathrm{G} 2 / \mathrm{M}$ cell cycle arrest in human endometrial cancer cells. Food Chem Toxicol 2011;49(8):1737-44.

21. Nugraheni M, Santoso U. Antioxidant activity and resistant starch content of $C$. tuberosus on different cooking method and its potential on glucose management in diabetic mice. Curr Res Nutr Food Sci J 2019;7(1):182-9.

22. Nugraheni M, Santoso U, Wuryastuti H. Phytochemical compounds and antioxidant activity of Coleus tuberosus flesh and peel on different solvent. Food Res 2018;2(5):460-7.

23. Santiago LA, Dayrit KC, Correa PCB, Mayor ABR. Comparison of antioxidant and free radical scavenging activity of triterpenes aamyrin, oleanolic acid and ursolic acid. J Nat Prod 2014;7:29-36.

24. Dai Y, Qiu XY, He YY, Zhang Q, Yang LG, Gao YT. Effects of scavenging DPPH free radical by oleanocic acid and ursolic acid. J Yunnan Univ Natl (Natural Sci Ed) 2012; 21:395-398.

25. Nur NM, Al-Jasabi SM. Antioxidant properties of maslinic acid extracted from Plumeria Rubra leaves. Int J Contemp Res Rev 2017;8(7):78-83.

26. Jamkhande PG, Pathan SK, Wadher SJ. In silico PASS analysis and determination of antimycobacterial, antifungal, and antioxidant efficacies of maslinic acid in an extract rich in pentacyclic triterpenoids. Int J Mycobacteriol 2016;5(4):417-25.

27. Parvez MK, Alam P, Arbab AH, Al-Dosari MS, Alhowiriny TA, Alqasoumi SI. Analysis of antioxidative and antiviral biomarkers $\beta$-amyrin, $\beta$-sitosterol, lupeol, ursolic acid in Guiera senegalensis leaves extract by validated HPTLC methods. Saudi Pharm J 2018;26(5):685-93.

28. Agatonovic-Kustrin S, Morton DW, Mizaton HH, Zakaria H. The relationship between major polyphenolic acids and stigmasterol to antioxidant activity in different extracts of Myrmecodia platytyrea. South Afri J Bot 2018;115:94-9.

29. Zhang L, Zhang T, Chang M, Lu M, Liu R, Jin Q, et al. Effects of interaction between $\alpha$-tocopherol, oryzanol, and phytosterol on the antiradical activity against DPPH radical. LWT 2019;112:108206.

30. Prades J, Vögler O, Alemany R, Gomez-Florit M, Funari SS, RuizGutiérrez V, et al. Plant pentacyclic triterpenic acids as modulators of lipid membrane physical properties. Biochim Biophys Acta Biomembr 2011;1808(3):752-60.

31. Zhao CR, Qu XJ. Nrf2-ARE signaling pathway and natural products for cancer chemoprevention. Cancer Epidemiol 2010;34(5):523-33.

32. Loboda A, Rojczyk-Golebiewska E, Bednarczyk-Cwynar B, Lucjusz Z, Jozkowicz A, Dulak J. Targeting Nrf2-mediated gene transcription by triterpenoids and their derivatives. Biomol Ther (Seoul) 2012;20(6):499.

33. Allouche Y, Warleta F, Campos M, Sanchez-Quesada C, Uceda M, Beltran G, et al. Antioxidant, antiproliferative, and pro-apoptotic capacities of pentacyclic triterpenes found in the skin of olives on MCF-7 human breast cancer cells and their effects on DNA damage. J Agric Food Chem 2011;59(1):121-30.

34. Mkhwanazi BN, Serumula MR, Myburg RB, Van Heerden FR, Musabayane CT. Antioxidant effects of maslinic acid in livers, hearts and kidneys of streptozotocin-induced diabetic rats: effects on kidney function. Ren Fail 2014;36(3):419-31.

35. Castellano JM, Garcia-Rodriguez S, Espinosa JM, Millan-Linares MC, Rada M, Perona JS. Oleanolic acid exerts a neuroprotective effect against microglial cell activation by modulating cytokine release and antioxidant defense systems. Biomolecules 2019;9(11):683.

36. Yin R, Li T, Tian JX, Xi P, Liu RH. Ursolic acid, a potential anticancer compound for breast cancer therapy. Crit Rev Food Sci Nutr 2018;58(4):568-74.

37. Cilla A, Attanzio A, Barberá R, Tesoriere L, Livrea MA. Antiproliferative effect of main dietary phytosterols and $\beta$-cryptoxanthin alone or combined in human colon cancer Caco-2 cells through cytosolic $\mathrm{Ca}+2-$ and oxidative stress-induced apoptosis. J Funct Foods 2015;12:282-93.

38. Oprean C, Mioc M, Csányi E, Ambrus R, Bojin F, Tatu C, et al. Improvement of ursolic and oleanolic acids' antitumor activity by complexation with hydrophilic cyclodextrins. Biomed Pharmacother 2016;83:1095-104.

39. Urias-Lugo DA, Heredia JB, Muy-Rangel MD, Valdez-Torres JB, Serna-Saldívar SO, Gutiérrez-Uribe JA. Anthocyanins and phenolic acids of hybrid and native blue maize (Zea mays L.) extracts and their antiproliferative activity in mammary (MCF7), liver (HepG2), colon (Caco2 and HT29) and prostate (PC3) cancer cells. Plant Foods Hum Nutr 2015;70(2):193-9.

40. Yadav D, Nath Mishra B, Khan F. 3D-QSAR and docking studies on ursolic acid derivatives for anticancer activity based on bladder cell line T24 targeting NF-kB pathway inhibition. J Biomol Struct Dyn 2019;37(14):3822-37.

41. Carneiro NVQ, Silva HBFDA, Silva RR, Carneiro TCB, Costa RS, Pires AO, et al. Sambucus australis modulates inflammatory response via inhibition of nuclear factor kappa B (NF-kB) in vitro. An Acad Bras Cienc 2019;91(1):1-12.

42. Hsum YW, Yew WT, Hong PLV, Soo KK, Hoon LS, Chieng YC, et al. Cancer chemopreventive activity of maslinic acid: suppression of COX-2 expression and inhibition of NF- $\mathrm{kB}$ and AP-1 activation in Raji cells. Planta Med 2011;77(02):152-7.

43. Zhao H, Liu J, Song L, Liu Z, Han G, Yuan D, et al. Oleanolic acid rejuvenates testicular function through attenuating germ cell DNA damage and apoptosis via deactivation of NF-kB, p53 and p38 signalling pathways. J Pharm Pharmacol 2017;69(3):295-304.

44. Li C, Yang Z, Zhai C, Qiu W, Li D, Yi Z, et al. Maslinic acid potentiates the anti-tumor activity of tumor necrosis factor $\alpha$ by inhibiting NF- $\kappa B$ signaling pathway. Mol Cancer 2010;9(1):1-13.

45. Yu Y, Wang J, Xia N, Li B, Jiang X. Maslinic acid potentiates the antitumor activities of gemcitabine in vitro and in vivo by inhibiting NF-kB-mediated survival signaling pathways in human gallbladder cancer cells. Oncol Rep 2015;33(4):1683-90.

46. Prasad S, Yadav VR, Sung B, Reuter S, Kannappan R, Deorukhkar A, et al. Ursolic acid inhibits growth and metastasis of human colorectal cancer in an orthotopic nude mouse model by targeting multiple cell signaling pathways: chemosensitization with capecitabine. Clin Cancer Res 2012;18(18):4942-53.

47. Iqbal J, Abbasi BA, Ahmad R, Mahmood T, Kanwal S, Ali B, et al. Ursolic acid a promising candidate in the therapeutics of breast cancer: current status and future implications. Biomed Pharmacother 2018;108:752-6.

48. Vundru SS, Kale RK, Singh RP. $\beta$-Sitosterol induces G1 arrest and causes depolarization of mitochondrial membrane potential in breast carcinoma MDA-MB-231 cells. BMC Complement Altern Med 2013;13(1):1-9.

49. Ho K, Yazan LS, Ismail N, Ismail M. Apoptosis and cell cycle arrest of human colorectal cancer cell line HT-29 induced by vanillin. Cancer Epidemiol 2009;33(2):155-60.

50. Attari F, Sepehri H, Delphi L, Goliaei B. Apoptotic and necrotic effects of pectic acid on rat pituitary GH3/B6 tumor cells. Iran Biomed J 2009;13(4):229-36.

51. Jeune MAL, Kumi-Diaka J, Brown J. Anticancer activities of pomegranate extracts and genistein in human breast cancer cells. J Med Food 2005;8(4):469-75.

52. Zhu Y, Huang H, Wu Y. Anticancer and apoptotic activities of oleanolic acid are mediated through cell cycle arrest and disruption of mitochondrial membrane potential in HepG2 human hepatocellular carcinoma cells. Mol Med Rep 2015;12(4):5012-8.

53. Samivel R, Nagarajan RP, Subramanian U, Khan AA, Masmali A, AlmubradT,etal.Inhibitoryeffectofursolicacidonultravioletbradiationinduced oxidative stress and proinflammatory response-mediated 

on cervical cancer cell lines 2022;10(01):164-171

senescence in human skin dermal fibroblasts. Oxid Med Cell Longev 2020; Article ID 1246510:1-17.

54. Wu DM, Zhao D, Li DZ, Xu DY, Chu WF, Wang XF. Maslinic acid induces apoptosis in salivary gland adenoid cystic carcinoma cells by Ca 2+-evoked p38 signaling pathway. Naunyn Schmiedebergs Arch Pharmacol 2011;383(3):321-30.

55. Maiyoa F, Moodley R, Singh M. Phytochemistry, cytotoxicity and apoptosis studies of $\beta$-sitosterol-3-oglucoside and $\beta$-amyrin from Prunus africana. Afr J Tradit Complement Altern Med 2016;13(4):105-12.

56. Zhang FH, Yan YL, Wang Y, Liu Z. Lactucin induces potent anticancer effects in HL-60 human leukemia cancer cells by inducing apoptosis and sub-G1 cell cycle arrest. Bangladesh J Pharmacol 2016;11(2):478-84.
57. Long H, Huang Q, Yu Y, Zhang Z, Yao Z, Chen H, et al. Dehydrocostus lactone inhibits in vitro gastrinoma cancer cell growth through apoptosis induction, sub-G1 cell cycle arrest, DNA damage and loss of mitochondrial membrane potential. Arch Med Sci 2019;15(3):765-3.

How to cite this article:

Nugraheni M, Windarwati W, Lastariwati B. Antioxidative, antiproliferative, and apoptotic effect of Coleus tuberosus flesh and peel ethanol extract on cervical cancer cell lines. J Appl Biol Biotech 2022; 10(01):164-171. 